\title{
EFFECTS OF PALM KERNEL SHELL ASH ON LIME-STABILIZED LATERITIC SOIL
}

\author{
Emeka Segun NNOCHIRI ${ }^{1 *}$, Olumide M. OGUNDIPE², Opeyemi E. OLUWATUYI ${ }^{3}$
}

\section{Abstract}

The research investigated the effects of palm kernel shell ash (PKSA) on lime-stabilized lateritic soil. Preliminary tests were performed on three soil samples, i.e., $L 1, L 2$ and $L 3$ for identification; the results showed that $L 1$ was $A-7-6, L 2$ was $A-7-6$, and $L 3$ was A-7-6. The optimum amount of lime for each of the soil samples was achieved. The optimum amount for L1 was 10\%, for $L 2,8 \%$ and for $L 3,10 \%$; at these values they recorded the lowest plasticity indexes. The further addition of PKSA was performed by varying the amount of PKSA and lime added to each of the soil samples. The addition of $4 \%$ PKSA+ $6 \%$ lime, the addition of $4 \%$ PKSA $+4 \%$ lime, and the addition of $4 \%$ PKSA + $6 \%$ lime increased the California Bearing Ratio (CBR) to the highest values for $L 1, L 2$ and $L 3$ from $8.20 \%$. It was concluded that PKSA can be a suitable complement for lime stabilization in lateritic soil.
Address

1* Department of Civil and Environmental Engineering, Afe Babalola University, Ado-Ekiti, Nigeria

2 Department of Civil Engineering, Ekiti State University, AdoEkiti, Nigeria

3 Department of Civil Engineering, Landmark University, OmuAran, Nigeria

*Corresponding author: segunemeka@yahoo.com

\section{Key words}

- Atterberg Limits,

- Lateritic soil,

- Lime stabilization,

- Palm kernel shell ash,

- Strength tests.

\section{INTRODUCTION}

A good and efficient transportation infrastructure is important for economic growth and the development of any community or state. It promotes mobility and reduces trade costs. In addition, it promotes market integration, thereby providing an avenue for the reduction of price volatility and the reallocation of resources in line with comparative advantages, Oyesiku et al. (2013). The importance of roads in the development of any nation can hardly be overemphasized, as they play an important role in the transportation of goods and services. This is commonly achieved in Nigeria through a vast network of roads that connect rural centres. Efforts at achieving the construction, of more roads are hindered by the high cost of their construction which is attributed to the nonavailability of suitable road building materials within the vicinity of most road projects. Laterite, a sedimentary rock deposit arising from the weathering of rocks, is one of the most common and readily available road building materials that can be sourced locally in Nigeria, Joel and Edeh (2015). Laterites (or lateritic soils) as a soil group instead of well-designed materials are mostly found in the leached soils of the humid tropics, where they were first studied. These soils are formed under weathering conditions productive of the process of laterization, the most important characteristic of which is the decomposition of ferro-alumino silicate materials and the permanent processes that produce lateritic soils. Lateritic soils are used in the construction of roads, highways, airfields and earth dams and for foundations of structures, Bello (2012). Lateritic soil in its natural state generally has a low bearing capacity and low strength due to its high clay content. When lateritic soil contains a large amount of clay materials, its strength and stability cannot be guaranteed under a load, especially in the presence of moisture. When lateritic soil consists of high plastic clay, the plasticity of the soil may cause cracks and damage to pavements, roadways, building foundations or any other civil engineering projects. The improvement in the strength and durability of lateritic soil in recent times has become imperative, which has encouraged researchers to use stabilizing materials that can be sourced locally at a very low cost. These local materials can be categorized as either agricultural or industrial waste, Ogunribido (2011). Soil stabilization can be defined as the process of blending and mixing materials 


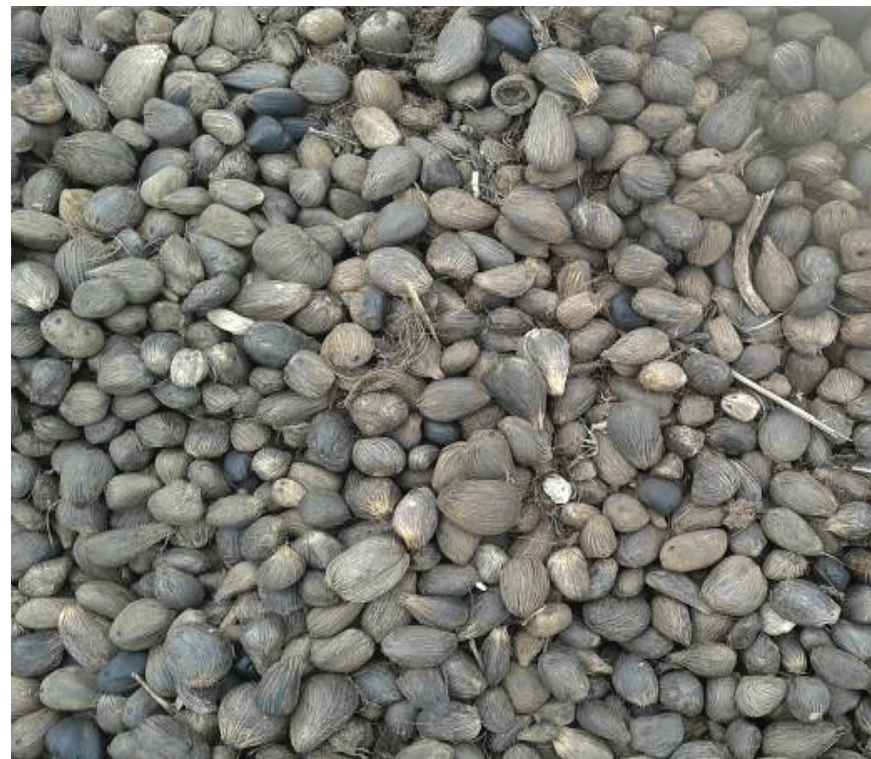

Fig. 1: Palm Kernel Shell

with soil to improve certain properties of the soil. The process may include the blending of soils to achieve a desired gradation or the mixing of commercially available additives that may alter the soil's gradation, texture or plasticity or act as a binder for cementation of the soil, Ogundipe (2013).

Palm kernel shell (PKS) is a by-product of the oil palm fruits. The oil palm plant (Elaeis guineensin) comes from West Africa, where it grows in the wild and has developed into an agricultural crop, www. palmoilhealth.org (2016).

The palm kernel shell, which is the crushed shell housing the palm kernel seed, is an economically valuable tree that is widespread throughout the tropics. The palm kernel shell can be regarded as a natural pellet and a high grade solid renewable fuel for burning. It can be combined with steam coal or burned at biomass power plants; it is usually blended with other grades of biomass. The palm kernel shell contains silicates that form a scale in boilers if too much shell is fed into a furnace. The residual shell is disposed of as gravel for the maintenance of plantation roads. Blacksmiths also buy the shells to use as fuel material in their casting and forging operations. They are yet to be utilized to a great extent as a construction material, but blended palm kernel shells have been used to modify lateritic soil because of their good interlocking characteristics, low specific gravity, and high porosity. Research has been conducted to see whether they can make suitable stabilizing agents for the improvement of soils for civil engineering construction, Ekeocha and Agwuncha (2014). According to Adeyemi and Joseph (2015), palm kernel shells have very low ash and sulphur content. Palm kernel shell ash (PKSA) is a by-product of the combustion of palm kernel shells under a controlled temperature of between 600 and $1000^{\circ} \mathrm{C}$.

According to Raheem et al. (2010), lime stabilization refers to the process of adding burnt limestone products such as calcuim oxide (i.e., quicklime) or calcium hydroxide $\left(\mathrm{Ca}(\mathrm{OH})_{2}\right)$ to soil in order to improve its properties. This process is similar to cement stabilization except that lime stabilization is suitable for soils with a high clay content.

According to Sadeeq et al. (2015), the effect of adding bagasse ash (BA) on lime-treated soil generally led to decrease in values of maximum dry density (MDD), also, the optimum moisture content $(\mathrm{OMC})$ increased continuously with increase in both lime and bagasse ash contents. Furthermore, the unconfined compressive strength (UCS) values increased with increase in both lime and bagasse ash having peak values at $6 \%$ bagasse ash content and decreased afterwards. In the case of the California Bearing Ratio (CBR), generally the CBR values recorded increased with higher lime content. Increase in CBR values was also recorded with bagasse ash content having its peak values at $6 \%$ bagasse ash content. All the unsoaked CBR values at $6 \%$ lime and also at 2 and $4 \%$ BA $/ 2$ and $4 \%$ lime contents and above met the $20-30 \%$ requirement for subbase.

According to Jha and Gill (2006), for a given Rice husk ash (RHA) content in the compaction tests, addition of RHA to the lime-stabilized soil decreased its maximum dry density (MDD) but resulted to increase in optimum moisture content (OMC) values. Adding RHA to the lime treated soil, resulted to increase in values of the unconfined compressive strength (UCS) until an optimum condition was reached. By introducing RHA to the lime-treated soil, additional amount of silica was available for reaction with lime leading to further increase in strength. The same can be said about California bearing ratio (CBR), addition of RHA further increased the CBR values, generally efficiency of lime stabilization may be increased by the addition of RHA.

\subsection{Location and Geology of the Study Area}

The study area lies within longitudes $7^{\circ} 18^{\prime} \mathrm{N}$ and $7^{\circ} 16^{\prime} \mathrm{N}$ north of the equator and between latitudes $5^{\circ} 09^{\prime} \mathrm{E}$ and $5^{\circ} 11.5^{\prime} \mathrm{E}$ of the Greenwich meridian. The study area is located within the pre-Cambrian crystalline rocks of the basement complex of southern Nigeria. The predominant rock types in the study area are charnockites, granite, gneiss and migmatitic rocks. At some sites in the study area these rocks have undergone deep weathering, Ogunribido (2011).

\subsection{Aim of Study}

This study examines the effects of palm kernel shell ash (PKSA) on lime stabilized lateritic soil.

\section{MATERIALS AND METHODS}

\subsection{Materials}

The materials used were lateritic soil samples, lime, palm kernel shell ash, and potable water. The lateritic soil samples were obtained from various existing borrow pits located in Akure, Nigeria. The palm kernel shell was obtained from a palm oil factory in Akure, burnt in a laboratory furnace under a controlled temperature of $900^{\circ} \mathrm{C}$, and sieved through a 75 -micron sieve. The contents that passed through the sieve were used in this study. The potable water was obtained from treated water available in the laboratory. Paper labels indicating the dates of extraction, the depths of extraction from the borrow pit, and their location were attached to the lateritic soil samples. The samples were placed on sacks in the laboratory to air dry them for a minimum of two weeks.

Sunlight and water were prevented from coming in contact with the lateritic soil during the process. The soil was regularly stirred to avoid local drying, i.e., for an even drying of the sample. The hydrated lime was kept safe to avoid any contact with moisture and any other material that could alter its properties. 


\subsection{Methods}

Preliminary tests (such as the material moisture content, specific gravity, particle size analysis and Atterberg limit tests) for the purpose of determining the soil's index properties were carried out on the samples. The lime, which was the major stabilizing material, was thereafter mixed with the samples in $0,2,4,6$ and $10 \%$ by weight of the soil samples in order to determine their optimum lime requirement. The Atterberg limits of the lime-stabilized soil samples were later determined. These characteristics were adopted as the control for the necessary evaluation of the effects of PKSA on the lime-stabilized samples. As the percentage content of the PKSA increased, the percentage content of the lime was reduced, but the addition of both stabilizers in percentages was ten percent at every stage of the mixtures involving L1 and L3 and was eight percent at every stage of the mixture involving $\mathrm{L} 2$.

\section{RESULTS AND DISCUSSIONS}

The natural moisture content of samples L1, L2, and L3 are $13.30 \%, 14.75 \%$ and $12.90 \%$ respectively. The moisture content of a soil chiefly depends on the void ratio; of the three samples, L2 had the highest void ratio, Bello et al. (2015).

The specific gravities of samples L1, L2 and L3 are 2.36, 2.32 and 2.44 respectively. The classification of soil stipulates that for a soil to be classified into the $\mathrm{A}-7$ groups, the percentage passing a BS

Tab. 1: Chemical composition of PKSA

\begin{tabular}{ll}
\hline Elemental Oxide & Weight Composition (\%) \\
\hline $\mathrm{CaO}$ & 8.79 \\
$\mathrm{~K}_{2} \mathrm{O}$ & 6.25 \\
$\mathrm{Al}_{2} \mathrm{O}_{3}$ & 11.40 \\
$\mathrm{SiO}_{2}$ & 54.81 \\
$\mathrm{Fe}_{2} \mathrm{O}_{3}$ & 0.36 \\
\hline
\end{tabular}

Source: Adeyemi and Joseph (2015)

Tab. 2: Preliminary test results

\begin{tabular}{llll}
\hline Property & L1 & L2 & L3 \\
\hline Natural moisture content (\%) & 13.30 & 14.75 & 12.90 \\
Percentage passing BS No 200 sieve & 55 & 51 & 55 \\
Liquid limit (\%) & 49.2 & 47.7 & 42.5 \\
Plastic Limit (\%) & 14.1 & 13.6 & 13.6 \\
Plasticity Index (\%) & 35.1 & 34.1 & 28.9 \\
Specific gravity & 2.36 & 2.32 & 2.44 \\
\hline AASHTO Classification & A-7-6 & A-7-6 & A-7-6 \\
\hline Maximum Dry Density (Kg/m $\left.{ }^{3}\right)$ & 1345 & 1385 & 1410 \\
Optimum Moisture Content (\%) & 16.20 & 13.80 & 17.30 \\
California Bearing Ratio (\%) & 9.25 & 12.20 & 8.20 \\
Unconfined Compressive Strength $\left(\mathrm{kN} / \mathrm{m}^{2}\right)$ & 375 & 490 & 415 \\
\hline
\end{tabular}

Tab. 3: Atterberg Limits for Lime Stabilization

\begin{tabular}{|c|c|c|c|c|}
\hline Samples & $\begin{array}{l}\text { Lateritic Soil } \\
+ \text { Lime (\%) }\end{array}$ & $\begin{array}{l}\text { Liquid Limit } \\
\text { (LL) }(\%)\end{array}$ & $\begin{array}{l}\text { Plastic Limit } \\
\quad(\mathrm{PL})(\%)\end{array}$ & $\begin{array}{c}\text { Plasticity } \\
\text { Index (PI) (\%) }\end{array}$ \\
\hline \multirow{6}{*}{ L1 } & 0 & 49.2 & 14.1 & 35.1 \\
\hline & 2 & 47.8 & 15.3 & 32.5 \\
\hline & 4 & 44.7 & 17.8 & 26.9 \\
\hline & 6 & 40.6 & 18.9 & 21.7 \\
\hline & 8 & 38.2 & 21.9 & 16.3 \\
\hline & 10 & 36.7 & 24.6 & 12.1 \\
\hline \multirow{6}{*}{ L2 } & 0 & 47.7 & 13.6 & 34.1 \\
\hline & 2 & 43.6 & 16.2 & 27.4 \\
\hline & 4 & 39.3 & 16.9 & 22.4 \\
\hline & 6 & 37.1 & 18.9 & 18.2 \\
\hline & 8 & 34.1 & 21.5 & 12.6 \\
\hline & 10 & 34.8 & 22.0 & 12.8 \\
\hline \multirow{6}{*}{ L3 } & 0 & 42.5 & 13.6 & 28.9 \\
\hline & 2 & 39.3 & 16.2 & 23.1 \\
\hline & 4 & 37.6 & 17.4 & 20.2 \\
\hline & 6 & 34.8 & 17.6 & 17.2 \\
\hline & 8 & 31.3 & 19.2 & 12.1 \\
\hline & 10 & 29.0 & 19.8 & 9.2 \\
\hline
\end{tabular}

Tab. 4: Atterberg limit tests for PKSA-lime stabilization.

\begin{tabular}{|c|c|c|c|c|c|}
\hline Sample & $\begin{array}{c}\text { \%PKSA by } \\
\text { weight }\end{array}$ & \begin{tabular}{|c} 
oLime by \\
weight
\end{tabular} & LL (\%) & PL (\%) & PI (\%) \\
\hline \multirow{9}{*}{ L1 } & 9 & 1 & 58.3 & 26.1 & 32.2 \\
\hline & 8 & 2 & 61.1 & 35.9 & 25.2 \\
\hline & 7 & 3 & 55.7 & 32.6 & 23.1 \\
\hline & 6 & 4 & 53.1 & 31.2 & 21.9 \\
\hline & 5 & 5 & 50.9 & 30.1 & 20.8 \\
\hline & 4 & 6 & 47.9 & 29.8 & 18.1 \\
\hline & 3 & 7 & 49.9 & 28.7 & 21.2 \\
\hline & 2 & 8 & 51.3 & 28.4 & 22.9 \\
\hline & 1 & 9 & 51.7 & 28.3 & 23.4 \\
\hline \multirow{7}{*}{ L2 } & 7 & 1 & 53.6 & 31.2 & 22.4 \\
\hline & 6 & 2 & 54.7 & 36.6 & 18.1 \\
\hline & 5 & 3 & 51.1 & 35.2 & 15.9 \\
\hline & 4 & 4 & 48.7 & 34.3 & 14.4 \\
\hline & 3 & 5 & 46.2 & 30.9 & 15.3 \\
\hline & 2 & 6 & 45.1 & 29.4 & 15.7 \\
\hline & 1 & 7 & 44.3 & 28.1 & 16.2 \\
\hline \multirow{9}{*}{ L3 } & 9 & 1 & 47.3 & 30.2 & 17.1 \\
\hline & 8 & 2 & 50.1 & 34.2 & 15.9 \\
\hline & 7 & 3 & 48.2 & 34.1 & 14.1 \\
\hline & 6 & 4 & 44.2 & 32.9 & 11.3 \\
\hline & 5 & 5 & 41.3 & 32.2 & 9.1 \\
\hline & 4 & 6 & 38.6 & 31.4 & 7.2 \\
\hline & 3 & 7 & 36.9 & 27.8 & 9.1 \\
\hline & 2 & 8 & 35.8 & 24.6 & 11.2 \\
\hline & 1 & 9 & 33.7 & 21.6 & 12.1 \\
\hline
\end{tabular}


Tab. 5: Maximum Dry Density and Optimum Moisture Content Results

\begin{tabular}{c|c|c|c}
\hline Sample & \% additive by weight & MDD $\left(\mathbf{k g} / \mathbf{m}^{3}\right)$ & OMC (\%) \\
\hline \multirow{3}{*}{ L1 } & $0 \%$ & 1345 & 16.2 \\
& $10 \%$ lime & 1310 & 22.7 \\
& $4 \%$ PKSA + 6\% Lime & 1287 & 25.6 \\
\hline \multirow{4}{*}{ L2 } & $0 \%$ & 1385 & 13.8 \\
& $4 \%$ LKSA + 4\% Lime & 1335 & 19.6 \\
& $0 \%$ & 1410 & 23.7 \\
L3 & $10 \%$ lime & 1365 & 20.6 \\
& $4 \%$ PKSA + 6\% Lime & 1330 & 23.1 \\
\hline
\end{tabular}

Tab. 6: CBR Values for Unsoaked Condition Results

\begin{tabular}{c|c|c}
\hline Sample & \% additive by weight & Unsoaked CBR (\%) \\
\hline \multirow{3}{*}{ L1 } & $0 \%$ & 9.25 \\
& $10 \%$ lime & 43.40 \\
& $4 \%$ PKSA + 6\% Lime & 28.30 \\
\hline \multirow{3}{*}{ L2 } & $0 \%$ & 12.20 \\
& $8 \%$ PKSA $+4 \%$ Lime & 49.20 \\
& $0 \%$ & 31.30 \\
\hline \multirow{3}{*}{ L3 } & $10 \%$ lime & 8.20 \\
& $4 \%$ PKSA $+6 \%$ Lime & 41.20 \\
& & 30.10 \\
\hline
\end{tabular}

Tab. 7: Unconfined Compressive Strength (UCS) Results

\begin{tabular}{c|c|c}
\hline Sample & \% additive by weight & $\left(\mathbf{k N} / \mathbf{m}^{2}\right)$ \\
\hline \multirow{3}{*}{ L1 } & $0 \%$ & 51.3 \\
& $4 \%$ PKSA $+6 \%$ Lime & 131.4 \\
& $10 \%$ lime & 168.9 \\
\hline \multirow{2}{*}{ L2 } & $0 \%$ & 46.8 \\
& $4 \%$ PKSA $+4 \%$ Lime & 94.6 \\
& $8 \%$ lime & 148.5 \\
\hline \multirow{3}{*}{ L3 } & $0 \%$ & 58.5 \\
& $4 \%$ PKSA $+6 \%$ Lime & 126.8 \\
& $10 \%$ lime & 175.2 \\
\hline
\end{tabular}

(British Standard) No 200 sieve must be more than 35\%. For all three soil samples, the percentages that passed the BS No 200 sieve are 55,51 and 55 respectively; all three values exceeded the maximum value of 35\% which must not be exceeded for soils of subgroups A-1, A-2 and A-3. Exceeding maximum value of $35 \%$ therefore suggests that the soil samples fall into any of these subgroups; A-4, A-5, A-6 and A-7. Furthermore, for a soil sample to be classified into the A - 7 group, its liquid limit must be of a minimum value of $40 \%$. The three
L1, L2 and L3 soil samples have the following liquid limit values: $49.2 \%, 47.7 \%$ and $42.5 \%$; the three values exceed the standard $40 \%$ liquid limit for A -7 group soils. For soil samples to be classified into the A - $7-6$ subgroup based on AASHTO (American Association of State Highway and Transportation Officials) classification system, the plasticity index (PI) of A $-7-6$ subgroup must be greater than L $\mathrm{L}-30$. For sample L1, PI (35.1) > 19.2; for sample L2, the PI is 34.1; and $34.1>17.7$; therefore, both soil samples rightly belong to the A7 - 6 subgroup. Also, sample L3 belonged to the A $-7-6$ subgroup, because the PI is 28.9 and (PI) 28.9. Garber and Hoel (2009).

From table 3, it can be seen that the plasticity indexes of the natural soil samples L1, L2 and L3 at $0 \%$ lime were $35.1 \%, 34.1 \%$ and $28.9 \%$ with corresponding liquid limit values of $49.2 \%, 47.7 \%$ and $42.5 \%$ and with corresponding plastic limit values of $14.1 \%, 13.6 \%$ and $13.6 \%$ respectively. According to Bello et al. (2015), these results indicate that the clay is of intermediate plasticity in nature. High plasticity is an indicator of potential swelling; clay is prone to large volume changes if PI is greater than or equal to $30 \%$, Amu et al. (2005). The addition of lime to $\mathrm{L} 1$ at $10 \%$ weight of the soil reduced the PI from the highest value at $35.1 \%$ to the lowest PI value of $12.1 \%$.

For L2, the addition of lime at $8 \%$ reduced the PI from the highest value at $34.1 \%$ to the lowest PI value of $12.6 \%$, and for L3, the addition of lime at $10 \%$ reduced the PI from the highest value at $28.9 \%$ to the lowest level at $9.2 \%$.

Table 4 indicates that for sample L1, the mixture of 9\% PKSA + $1 \%$ lime has a higher PI value of $32.2 \%$ compared with $12.1 \%$ at $10 \%$ Lime, which was the value obtained from the optimal mixture of the lime. It was also observed that the PI values were reduced with the addition of PKSA in the mixture. The PI value for the optimal mixture was a result of $4 \%$ PKSA $+6 \%$ lime, which was $18.1 \%$. From the foregoing, there is an indication that the addition of PKSA enhanced the soil properties by reducing the PI. For samples L2 and L3, the addition of PKSA enhanced the soil properties by reducing the PI. The PI was at $4 \%$ lime $+4 \%$ PKSA in the optimal mixture for L2. The PI was at $4 \%$ PKSA $+6 \%$ lime in the optimal mixture for L3.

The reduction in the plasticity is attributed to the change in the soil's nature (its granular nature after flocculation and agglomeration) and the modified soil is as crumbly as silt soil, which is characterized by a low surface area and a low liquid limit because of the plastic nature of the lime, Ibtehaj et al. (2014).

\subsection{Compaction characteristics}

From table 5, it can be seen that the maximum dry density (MDD) of natural soil sample L1 was $1345 \mathrm{Kg} / \mathrm{m}^{3}$, and the optimum moisture content (OMC) was $16.2 \%$; the addition of $10 \%$ lime reduced the MDD to $1310 \mathrm{Kg} / \mathrm{m}^{3}$ and increased the OMC to $22.7 \%$, while the addition of $4 \%$ PKSA $+6 \%$ lime further decreased the MDD to $1287 \mathrm{Kg} / \mathrm{m}^{3}$ and increased the OMC to $25.6 \%$.

The natural soil sample L2 has an MDD of $1385 \mathrm{Kg} / \mathrm{m}^{3}$ and an OMC value of $13.80 \%$; the addition of $8 \%$ lime reduced the MDD to $1335 \mathrm{Kg} / \mathrm{m}^{3}$, and the addition of $4 \%$ PKSA $+4 \%$ lime further reduced the MDD to $1317 \mathrm{Kg} / \mathrm{m}^{3}$. At these three points, the OMC increased from $13.8 \%$ ( $0 \%$ lime) to $19.6 \%$ (at $8 \%$ lime) and finally to $23.7 \%$ (at $4 \%$ PKSA $+4 \%$ lime).

The natural soil sample L3 has its MDD value as $1410 \mathrm{Kg}$ / $\mathrm{m}^{3}$ and $\mathrm{OMC}$ value as $17.3 \%$. At $10 \%$ lime, the MDD reduced to $1365 \mathrm{~kg} / \mathrm{m}^{3}$ and further reduced to $1330 \mathrm{Kg} / \mathrm{m}^{3}$ at $4 \%$ PKSA $+6 \%$ lime. At $10 \%$ lime, the $\mathrm{OMC}$ value was $20.6 \%$, and at $4 \%$ PKSA + $6 \%$ lime, the OMC value was $23.1 \%$. This general decreased in values of MDD may be attributed to the flocculation and agglomeration of clay particles due to cation exchange leading to corresponding decrease in dry density. The low MDD may also be attributed to 
the dispersal structure of the soil in the presence of the polar organic liquid, which consequently leads to reduced MDD. Decrease in MDD of the treated soils with lime and PKSA may be due to the low specific gravity value of lime and PKSA compared to that of the natural lateritic soil.

The observed increase in optimum moisture content (OMC) may be due to increased demand for water which commensurates with higher amount of lime/PKSA required for hydration reaction and dissociation needed for cation exchange reaction, Sadeeq et al., (2015).

\subsection{California Bearing Ratio.}

From table 6, the unsoaked CBR values of the samples are as follows: for sample L1, the CBR of the natural soil sample is $9.25 \%$, which is just good enough for use as subgrade material, FMWH (1997). With $10 \%$ lime added, the CBR increased to $43.40 \%$, and with the addition of $4 \%$ PKSA $+6 \%$ lime, it reduced to $28.30 \%$. For sample L2, the natural soil sample had an unsoaked CBR value of $12.20 \%$. With the addition of $8 \%$ lime, it rose to $49.4 \%$ and finally reduced to $31.3 \%$ with the addition of $4 \%$ PKSA $+4 \%$ lime. The natural soil sample L3 has a CBR value of $8.20 \%$; with the addition of $10 \%$ lime, the CBR value increased to $41.20 \%$. The addition of $4 \%$ PKSA $+6 \%$ lime reduced the CBR to $30.10 \%$. The increase in strength can be attributed to the formation of cementing materials or binders comprised of Calcium Silicate Hydrates (CASH), which come into being as a result of the reaction between the Calcium hydroxide in the soil water and the silicates and aluminates in the soil, Jaritngam et al. (2014). Unsoaked CBR values of samples L2 and $\mathrm{L} 3$ at optimum states are $31.30 \%$ and $30.10 \%$, these values adequately meets the requirements for sub base, since the required value for sub base is unsoaked CBR value of $30 \%$, Federal Ministry of Works and Housing, (1997). Decrease in values of unsoaked CBR when compared to stabilizing with lime alone may be due to the excess PKSA introduced into the soil and therefore forming weak bonds between the soil and the cementitious compounds formed, Fattah et al., (2013).

\subsection{Unconfined Compressive strength (UCS)}

Table 7 shows the UCS value of the natural soil sample L1 was $51.3 \mathrm{kN} / \mathrm{m}^{2}$. With the addition of $4 \%$ PKSA $+6 \%$ Lime, the UCS value rose to $131.4 \mathrm{kN} / \mathrm{m}^{2}$, while with the addition of $10 \%$ lime, it further rose to $168.9 \mathrm{kN} / \mathrm{m}^{2}$. For sample L2, the UCS value of the natural soil sample was $46.8 \mathrm{kN} / \mathrm{m}^{2}$. With the addition of $4 \%$ PKSA $+4 \%$ lime, the UCS value increased to $94.6 \mathrm{kN} / \mathrm{m}^{2}$. The addition of $8 \%$ lime further increased the UCS value to $148.5 \mathrm{kN} / \mathrm{m}^{2}$. Sample L3 in a natural state had a UCS value of $58.5 \mathrm{kN} / \mathrm{m}^{2}$. With the addition of $4 \%$ PKSA $+6 \%$ lime, the UCS value increased to $126.8 \mathrm{kN} / \mathrm{m}^{2}$. The addition of $10 \%$ lime further increased the UCS value to 175.20 $\mathrm{kN} / \mathrm{m}^{2}$. The increase in the UCS values can be attributed to the ion exchange at the surface of clay particles. The $\mathrm{Ca}^{2+}$ in cement kiln dust (CKD) reacted with the lower valence metallic ions in the clay microstructure which resulted in agglomeration of clay particles. The increase in the UCS values was mainly due to the formation of some compounds such as Calcium Silicates Hydrates (CSH) and Calcium Aluminate Hydrates (CAH) and microfabric changes which are responsible for strength gain, Sadeeq et al.,(2015).

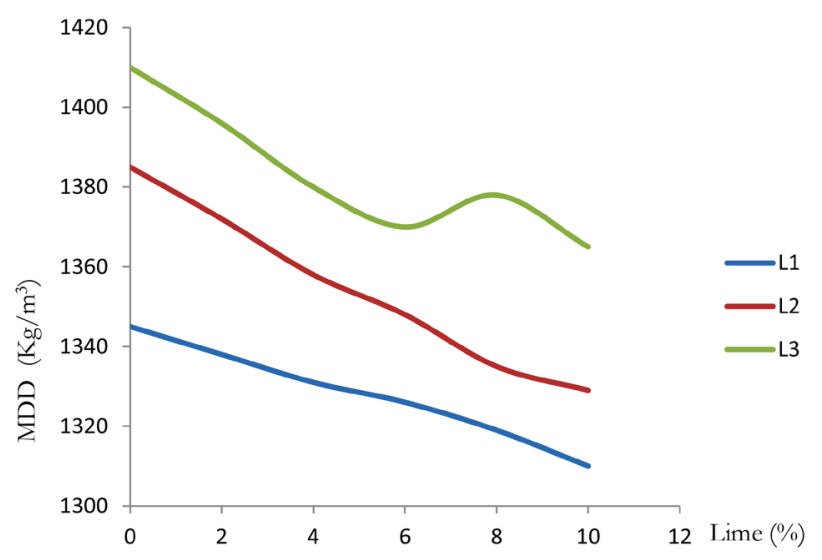

Fig. 2: Effect of lime on the MDD of the soil samples

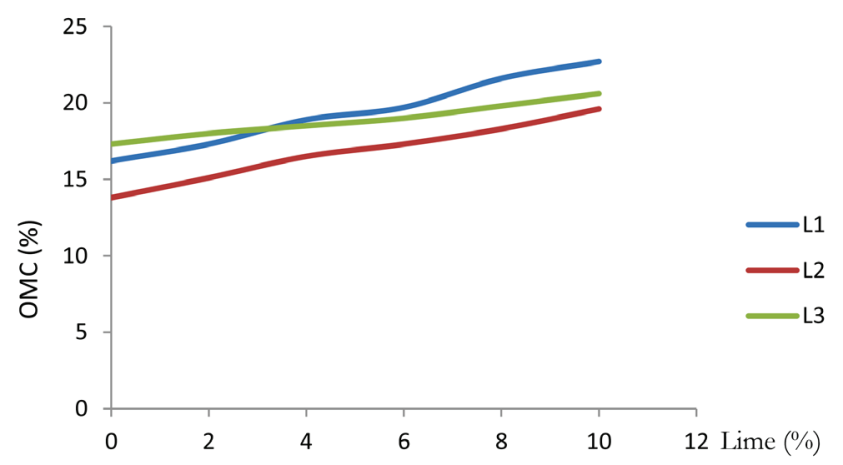

Fig. 3: Effect of lime on the OMC of the soil samples

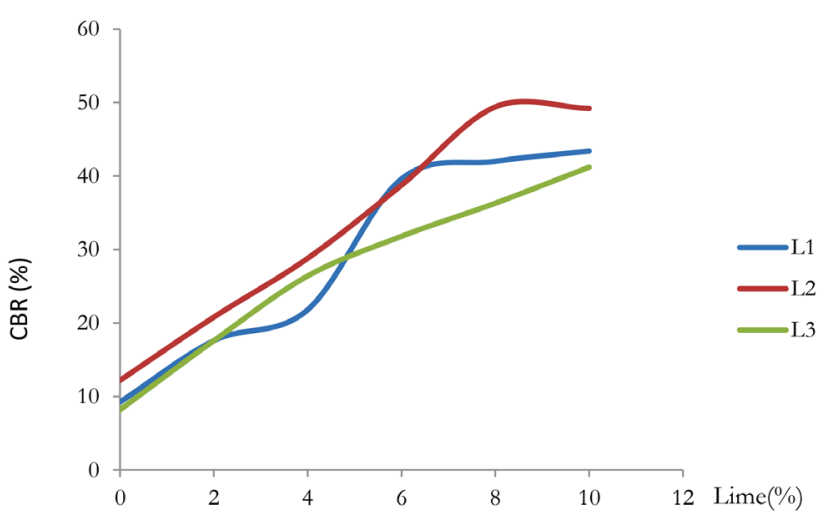

Fig. 4: Effect of lime on the CBR of the soil samples

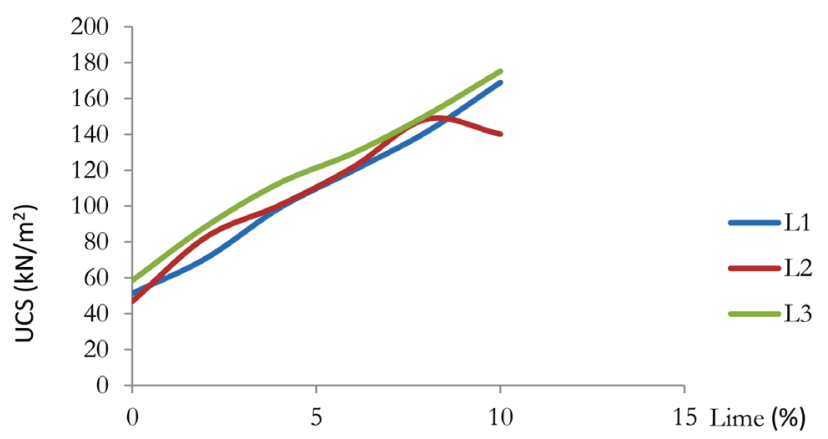

Fig. 5: Effect of lime on the UCS of the soil samples 


\section{CONCLUSION}

The procedures for the various tests were carried out in accordance with those stipulated in British Standard (BS) 1377 (1990) and British Standards (BS) 1924 (1990).

The soil samples L1, L2 and L3 were classified into the A - 7-6, A- 7-6, and A $-7-6$ subgroups. These subgroups fall within the silty-clay category under a general classification.

Addition of PKSA and Lime significantly reduced the values of liquid limit and plasticity index, an indication of soil improvement. The optimum states of samples L1, L2 and L3 are 4\% PKSA $+6 \%$ Lime, $4 \%$ PKSA $+4 \%$ Lime and $4 \%$ PKSA $+6 \%$ Lime because at these states the least values of plasticity indexes were recorded.

For samples L1, L2 and L3, the values of maximum dry density decreased from 1345,1385 and $1410 \mathrm{~kg} / \mathrm{m}^{3}$ all at natural states to 1287,1317 and $1330 \mathrm{~kg} / \mathrm{m}^{3}$ at optimum states of $4 \%$ PKSA $+6 \%$ Lime, 4\% PKSA + 4\% Lime and 4\% PKSA + 6\% Lime respectively. Values of optimum moisture content (OMC) increased from $16.2 \%$, $13.8 \%$ and $17.3 \%$ for samples L1, L2 and L3 to 25.6, 23.7 and $23.1 \%$ respectively at their optimum states of $4 \%$ PKSA $+6 \%$ Lime, $4 \%$
PKSA $+4 \%$ Lime and $4 \%$ PKSA $+6 \%$ Lime.

The California bearing ratio (CBR) values at the optimum states indicated appreciable improvement from the natural states, at the natural states of samples L1, L2 and L3, the CBR values were 9.25, 12.20 and $8.20 \%$ and at their optimum states, the values of CBR became $28.30 \%, 31.30 \%$ and $30.10 \%$. Ditto, in the case of unconfined compressive strength values, at the optimum states, there was appreciable improvement from the natural states.

The results of this study clearly demonstrated a significant improvement in the strength properties of the lime-stabilized samples. The Palm Kernel Shell Ash can therefore be said to be a suitable complement for lime stabilization in lateritic soils.

\section{Acknowledgements}

The authors hereby express their gratitude to Engr. Moses Tanimola and all the technical crew of the Geotechnical Laboratory of the Federal University of Technology, Akure, Nigeria. 


\section{REFERENCES}

Adeyemi, E. A. - Joseph, O. A. (2015) Comparative Analysis of Ekiti State Soil Stabilized with Different Additives. Asian Journal of Science and Technology. Vol. 06, No 12, pp. 2054-2058.

Amu, O. O. - Fajobi, A. B. - Oke, B. O. (2005) Effect of egg shell powder on the stabilizing potential of lime on an expansive clay soil, Journal of Applied Sciences, Vol. 5, No 8, pp. 1474 - 1478.

Bello, A. A. (2012) Regression analysis between properties of subgrade lateritic soil. Leonardo Journal of Sciences, No 21, pp. 99108. ISSN 1583-0233.

Bello, A. A. - Ige, J. A. - Ayodele, H. (2015) Stabilization of Lateritic Soil with Cassava Peels Ash. British Journal of Applied Science and Technology 7(6): 642-650.

British Standards (BS) 1377. (1990) Methods of Tests for Soils for Civil Engineering Properties. London: British Standards Institution, London, U.K., p. 143.

British Standards (BS) 1924. (1990) Methods of Test for Stabilized Soils. British Standards Institutions. London, U.K.

Ekeocha, N. E. - Agwuncha, F. N. (2014) Evaluation of palm kernel shells for use as stabilizing agents of lateritic soils. Asian Transactions on Basic and Applied Sciences (ATBAS ISSN: 2221 4291) vol. 04 Nọ 02.

Fattah, M. Y. - Rahil, F. H. - Al-Soudany, K.Y.H. (2013) Improvement of Clayey Soil Characteristics Using Rice Husk Ash, Journal of Civil Engineering and Urbanism, Vol. 3, Nọ 1: 12-18.

Federal Ministry of Works and Housing (1997) General Specifications for Roads and Bridges, Vol. 11, Federal Highway Department, FMWH: Lagos, Nigeria

Garber, N. J. - Hoel, L. A. (2009) Traffic and Highway Engineering, 4th edition, Canada, Cengage Learning, Chapter 17, p. 909.

Ibtehaj, T. J., Mohd, R. T., Zaid, H. M., Tanveer, A. K. (2014) Soil stabilization using lime: Advantages, disadvantages and propos- ing a potential alternative. Research Journal of Applied Sciences. Engineering and Technology 8(4):510 - 520 .

Jaritngam, S. - Somchaimiek, O. - Taneerananon, P. (2014) Feasibility of lateritic - cement mixture as pavement base course aggregate. IJST, Transaction of Civil Engineering, vol. 38, Nọ. 11, pp. $275-284,2014$.

Jha, J. N. - Gill, K. S. (2006). Effect of Rice Husk Ash on Lime Stabilization of Soil. J. Inst. Eng.. (India), 87: 33 - 39.

Joel, M. - Edeh, J. E. (2015) Comparative Analysis of Cement and Lime Modification of Ikpayongo Laterite for Effective and Economic Stabilization. Journal of Emerging Trends in Engineering and Applied Sciences (JETEAS) 6(1): $49-56$.

Ogundipe, O. M. (2013) An Investigation into the Use of Lime-Stabilized Clay as Subgrade Material. International Journal of Scientific and Technology Research. Vol. 2, Nọ 10, Oct., 2013.

Ogunribido, T. H. T. (2011) Potentials of Sugar Cane Straw Ash for Lateritic Soil Stabilization in Road Construction. International Journal of Science Emerging Technology, Vol. 3, Nọ. 5.

Oyesiku, K. - Onakoya, A.B. - Folawemo, A. (2013) The empirical analysis of transport infrastructure investment and economic growth in Nigeria. Journal: Social Sciences, Science PG; 2(6): $179-188$.

Raheem, A. A. - Bello, O. A. - Makinde, O.A. (2010) A Comparative Study of Cement and Lime-Stabilized Lateritic Interlocking Blocks. Pacific Journal of Science and Technology. Vol. 11, Nọ 2, 2010.

Sadeeq, J. A. - Ochepo, J. - Salahudeen, A. B. - Tijjani, S. T. (2015). Effect of Bagasse Ash on Lime Stabilized Lateritic Soil. Jordan Journal of Civil Engineering, Volume 9, No 2.

Sustainable Malaysian Palm Oil, www.palmoilhealth.org, (accessed 10/10/2016) 